\title{
Use of Estradiol Cypionate to induce ovulation in buffalo raised in floodplain areas of Itacoatiara, Amazonas
}

\author{
[Uso do cipionato de estradiol na indução da ovulação de búfalas criadas em \\ várzea da região de Itacoatiara, Amazonas] \\ J.H.A. Weiller ${ }^{1}$, M.V.C. Ferraz Júnior ${ }^{2}$, F. Jacobs Dias ${ }^{3}$, G.Y. Hattori ${ }^{4}$ \\ ${ }^{1}$ aluno de pós-graduação - Faculdade de Ciências Agrárias - Universidade Federal do Amazonas - Manaus, AM \\ ${ }^{2}$ Instituto de Ciências Sociais, Educação e Zootecnia - Universidade Federal do Amazonas - Parintins, AM \\ ${ }^{3}$ Faculdade de Ciências Agrárias - Universidade Federal do Amazonas - Manaus, AM \\ ${ }^{4}$ Instituto de Ciências Exatas e Tecnologia - Universidade Federal do Amazonas - Itacoatiara, AM
}

\begin{abstract}
This study aimed to determine the efficiency of estradiol cypionate (EC) as an ovulation inducer in a Timed Artificial Insemination protocol. 69 buffalo cows received an intravaginal progesterone device and $2 \mathrm{mg}$ of estradiol benzoate (EB) at D0. On D9, the intravaginal device was removed and $0.53 \mathrm{mg}$ of prostaglandin (PGF2 $\alpha$ ) and 400UI of equine chorionic gonadotrophin (eCG) were applied. The cows were distributed into two groups: the first group received $1 \mathrm{mg}$ of EC (ECG) in D9, and the second group received 1mg of EB (EBG) in D10. Inseminations occurred on D11. Ovarian activity and pregnancy diagnosis were analyzed by ultrasonography. There was no difference $(\mathrm{P}>0.05)$ in follicular diameter $(9.6 \pm 0.89 \mathrm{~mm}$ vs. $10.7 \pm$ $1.12 \mathrm{~mm} ; \mathrm{P}=0.06)$, in ovulation rate $(90.9 \%$ vs. $90.9 \% ; \mathrm{P}=1)$ and pregnancy rate $(58.8 \%$ vs. $62.9 \% ; \mathrm{P}=0.79)$, however, buffalo cows from the ECG treatment have less time between P4 removal and ovulation when compared to EBG buffalos $(37.4 \mathrm{~h}$ vs. $52.8 \mathrm{~h}$; $\mathrm{P}=0.001)$, respectively. Thus, it was concluded that the implantation of TAI in the floodplain of Amazonas is feasible and the use of EC results in successful rates, similar to EB.
\end{abstract}

Keywords: Bubalus bubalis, estradiol esters, insemination, floodplain

\section{RESUMO}

O objetivo deste trabalho foi determinar a eficiência do cipionato de estradiol (CE) como indutor de ovulação em um protocolo de inseminação artificial de tempo fixo. Para isso, 69 búfalas receberam no DO um dispositivo intravaginal de progesterona e $2 \mathrm{mg}$ de benzoato de estradiol (BE). No D9, o dispositivo intravaginal foi removido e foram aplicados $0,53 \mathrm{mg}$ de prostaglandina ( $P G F 2 \alpha)$ e $400 U I$ de gonadotrofina coriônica equina (eCG), para, então, os animais serem divididos em dois grupos: um deles (GCE) recebeu $1 \mathrm{mg}$ de CE no D9, e o outro (GBE) recebeu $1 \mathrm{mg}$ de BE 24 h após. As inseminações ocorreram no D11. A atividade ovariana e o diagnóstico de prenhez foram avaliados por ultrassonografia. Não houve diferença $(P>0,05)$ no diâmetro folicular $(9,6 \pm 0,89 \mathrm{~mm}$ vs. $10,7 \pm 1,12 \mathrm{~mm} ; P=0,06)$, na taxa de ovulação $(90,9 \%$ vs. $90,9 \% ; P=1)$ e na taxa de prenhez $(58,8 \%$ vs. $62,9 \% ; P=0,79)$, no entanto búfalas do tratamento $G C E$ apresentaram menor tempo entre a remoção da P4 e a ovulação, quando comparadas com as búfalas do GBE (37,4h vs. 52,8h; $P=0,001)$, respectivamente. A implantação da IATF nas várzeas do Amazonas é viável e a utilização do CE resulta em taxas de sucesso similares ao BE.

Palavras-chave: Bubalus bubalis, ésteres de estradiol, inseminação, várzea

\section{INTRODUCTION}

Buffalo farming is mostly exploited in the Amazonian region by small producers, with little use of technology, and mainly intended for the production of meat, milk and derivatives, being extensive systems in mixed areas of floodplain and solid ground properties (Lourenço Junior, 2005). However, according to Cassiano et al. (2004), one of the existing challenges in the

Recebido em 2 de junho de 2020

Aceito em 8 de setembro de 2020

E-mail: jadersonweiller@hotmail.com 
Amazonian region that proves to be an obstacle is the advance of reproductive efficiency and genetic improvement through biotechniques applied to animal reproduction, with extensive breeding and low food supply during a certain period of the year.

Among biotechniques, although Artificial Insemination (AI) is considered one of the most used techniques among domestic animals, in buffaloes, AI has its use limited by factors related to the difficulty in identifying estrus (Singh and Balhara, 2016). The clinical signs of estrus in a female buffalo are discreet, such as the discharge of vaginal mucus that is only detected in the estrus buffalo when the vagina is massaged by rectal palpation (Ali and Fahmy, 2007). To avoid this problem in buffalos, since the late nineties, research has been carried out to evaluate the effectiveness of different ovulation synchronization protocols for artificial fixed-time insemination (TAI) (Baruselli et al., 2003). The most used hormonal protocols for TAI are Ovsynch and progesterone-based ones; however, the cost of the progesterone-based protocol is higher than the Ovsynch protocols (Carvalho et al., 2017).

Although the progesterone-based hormonal protocol is the most efficient (Baruselli et al., 2007), studies are still needed to find cheaper alternative implantation protocols that require fewer days of management. Studies on the use of estradiol cypionate as an ovulation inducer are required to evaluate its use in ovulation induction in protocols for buffalo based on progesterone and to verify the efficiency of this protocol in buffalo extensively reared in the floodplain areas of the Amazonian region. The objective of this experiment was to compare the reproductive performance of buffalo submitted to TAI using EC (Estradiol Cypionate) or EB (Estradiol Benzoate) as an ovulation inducer.

\section{MATERIAL AND METHODS}

The experiment was carried out on an Imperial farm, located on the banks of the Urubu River (Latitude: $02^{\circ} 59^{\prime} 58.5^{\prime \prime} \mathrm{S}$; Longitude: $58^{\circ} 29^{\prime}$ 59.2 " O), near Itacoatiara city in the State of Amazonas, Brazil. The experiment site is classified as mixed property, considering that there is a floodplain area and dry land. In this property, the animals stay around 8 months of the year in the floodplain areas and 4 months in the dry land area. The property has about $1,066.5$ ha of total area, with 102 ha of pasture cultivated in dry land area and 190.5 ha of native pasture in the floodplain area. The buffaloes (Bubalus bubalis) used in the experiment came from two properties located in Itacoatiara and from one property located in Boa Vista do Ramos, both cities of the State of Amazonas, Brazil. During the buffalo selection period, the farm facilities, where the experiment was carried out, underwent renovations and an alternative wooden structure was built to contain the animals.

In the beginning of January 2019, the period of the year considered as rainy and the beginning of the rivers flooding, 112 crossbred buffalo cows were selected and transported to the Imperial Farm. Only buffaloes bred in floodplain areas, between 20 to 50 days postpartum, and with body condition scoring $(\mathrm{BCS}) \geq 3$ were selected. All females were identified and submitted to Brucellosis and Tuberculosis tests. 30 days after the animal's arrival, in February 2019, gynecological examinations were performed through rectal palpation and ultrasonography (5.0 $\mathrm{MHz}$ linear transducer, Mindray DP 2200 VET, China), and the females diagnosed with pregnancy were separated from the herd and returned to the original properties. Out of 112 crossbred buffaloes, 69 empty lactating cows were selected. The selected females were kept, without the presence of a bull, in an extensive system using native lowland pastures, with a predominance of the Marreca (Leersia hexandra Sw.) and the colony (Brachiaria mutica) grasses throughout the experiment.

The local pasture was characterized by the aid of a $1 \mathrm{~m}^{2}$ square, launched 5 times, randomly, to assess the forage mass and botanical composition. The chemical analysis of the forage was carried out after the collected samples were dried in a ventilation oven at $55^{\circ} \mathrm{C}$ for 72 hours and ground in a Willey mill with a $1 \mathrm{~mm}$ sieve. Then analyzed for dry matter (DM), mineral matter (MM) and crude protein (CP), according to the Association of Official Analytical Chemists (AOAC, 1990), and neutral detergent fiber (NDF) and acid detergent fiber (ADF) according to Van Soest et al. (1991). The analysis of the chemical composition of the forages showed the predominance of grasses with about $5 \%$ of $\mathrm{CP}$ and with NDF of about $70 \%$ (Table 1). 
Table 1. Chemical composition (\%) of the Marreca (Leersia hexandra Sw.) and Colônia (Brachiaria mutica) grasses, predominant in the floodplain area of the Imperial Farm used as food by buffaloes

\begin{tabular}{lcc} 
Parameters & $\begin{array}{c}\text { Marreca } \\
\text { Grass }\end{array}$ & $\begin{array}{c}\text { Colônia } \\
\text { Grass }\end{array}$ \\
\hline $\mathrm{DM}$ & 42,20 & 42,30 \\
$\mathrm{MM}$ & 7,50 & 7,90 \\
$\mathrm{CP}$ & 5,02 & 4,30 \\
$\mathrm{NDF}$ & 75,30 & 67,40 \\
$\mathrm{ADF}$ & 43,70 & 41,80 \\
\hline (DM = dry matter; MM = mineral matter; $\mathrm{CP}=$ crude \\
protein; NDF = neutral detergent fiber; $\mathrm{ADF}=$ acid \\
detergent fiber).
\end{tabular}

All experimental procedures were approved by the Ethics Committee on the Use of Animals (CEUA) of the Federal University of Amazonas (UFAM), under number 062/2018. The 69 buffaloes were divided into two lots, due to the number of intravaginal implants (40 units) purchased for the beginning of the experiment, which occurred in February 2019. In the first batch, 39 buffaloes received a new intravaginal progesterone device ( $1 \mathrm{~g} \quad \mathrm{P} 4)$ and $2.0 \mathrm{mg}$ intramuscular (IM) of EB in the morning, on a random day of the estrous cycle (D0). On D9 in the morning, the intravaginal device of $\mathrm{P} 4$ was removed and $0.53 \mathrm{mg}$ im of $\mathrm{PGF}_{2 \alpha}$ (Cloprostenol sodium) and 400UI im of equine chorionic gonadotrophin (eCG) were applied.

The buffaloes were randomly divided into Estradiol Cypionate Group (ECG) and Estradiol Benzoate Group (EBG). On D9 the 20 buffaloes of the ECG received 1.0mg of EC (Estradiol Cypionate) in the morning and 24 hours later, on D10, only 19 buffaloes of the EBG received $1.0 \mathrm{mg}$ of EB. All buffaloes in the first batch were submitted to TAI $56 \mathrm{~h}$ after the removal of the intravaginal progesterone implant (D11, in the afternoon). The two hormonal protocols of TAI used are illustrated in Figure 1.

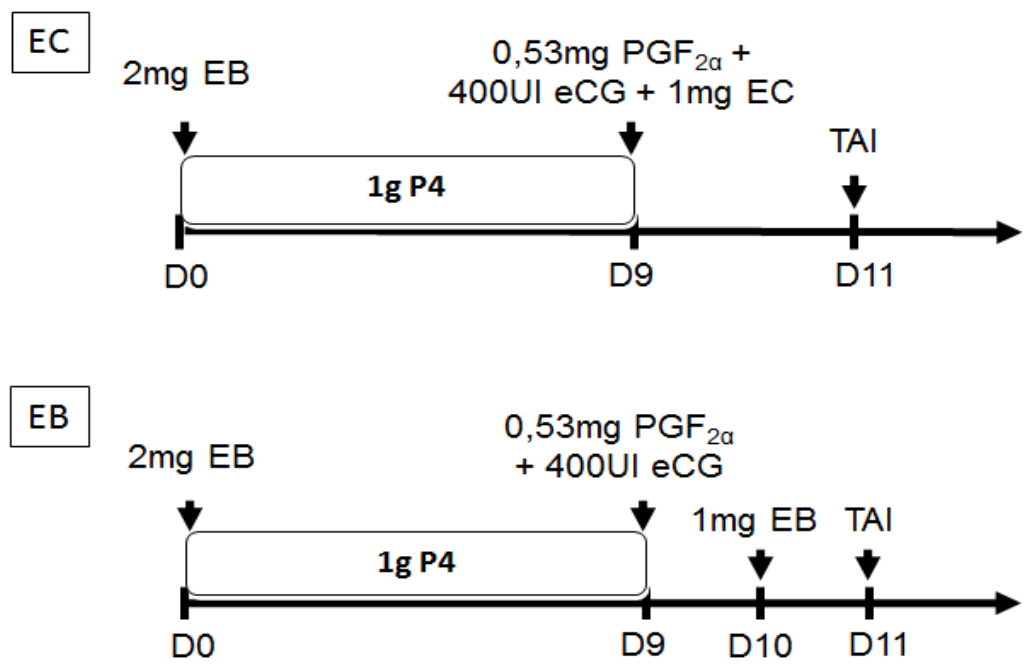

Figure 1. Schematic diagram of estradiol benzoate (EB) and estradiol cypionate (CE) protocols based timed artificial insemination (TAI), using cloprostenol sodium $\left(\mathrm{PGF}_{2 \alpha}\right)$ and equine chorionic gonadotrophin (eCG).

In the second batch, 30 buffaloes were divided into ECG (14 cows) and EBG (16 cows) and submitted to TAI using the same procedures described in the first batch, but with an intravaginal progesterone device previously used for nine days. Inseminations were carried out by two experienced professionals using frozen semen from a bull that had its fertility evaluated and guaranteed by a semen collection and marketing center. To determine estrus and evaluate the positive reaction to the effect of hormonal therapy, at the time of insemination (D11), the following criteria were used in the 69 buffaloes: presence of vaginal discharge, increased uterine tone and the ease of the passage of the semen applicator in the cervix.

To assess follicular dynamics, time to ovulation and ovulation rate, the follicles in the ovaries of 11 buffaloes per treatment were evaluated at D0 
and D9 at D12 (24-hour interval) by ultrasonography $(5.0 \mathrm{MHz}$ linear transducer, Mindray DP 2200 VET, China). All animals in the experiment were submitted to ultrasonography to diagnose pregnancy more than 30 days after artificial insemination. The randomized block design was adopted for data analysis, using the simultaneous TAI group as a blocker. The time for ovulation was analyzed using the MIXED procedure and the variables ovulation rate, signs of estrus, and pregnancy rates were analyzed using the GLIMMIX procedure (using the binominal distribution as an option). The size of the largest follicle was analyzed using repeated measures over time using the MIXED procedure with the compound symmetric matrix. All data were analyzed using the SAS 9.3 statistical program.

\section{RESULTS}

After the implementation of the ovulation synchronization protocols, the follicular diameter of the buffaloes was $10.15 \pm 1.00 \mathrm{~mm}$. The averages found for the EC and EB groups were $9.6 \pm 0.89 \mathrm{~mm}$ and $10.7 \pm 1.12 \mathrm{~mm}$, respectively. No significant difference was found in the comparison between treatments, $(\mathrm{P}=0.064)$. There was no significant difference between the experimental groups for the ovulation rate variables, each group had an ovulation rate of $90.9 \%(\mathrm{P}=1)$. A significant difference in the time of ovulation (37.4h vs. $52.8 \mathrm{~h} ; \mathrm{P}=0.001)$ was observed, for ECG and EBG, respectively, with a longer interval between the removal of the P4 device and the time of ovulation in the subgroup. EB compared to the EC subgroup (Figure 2).

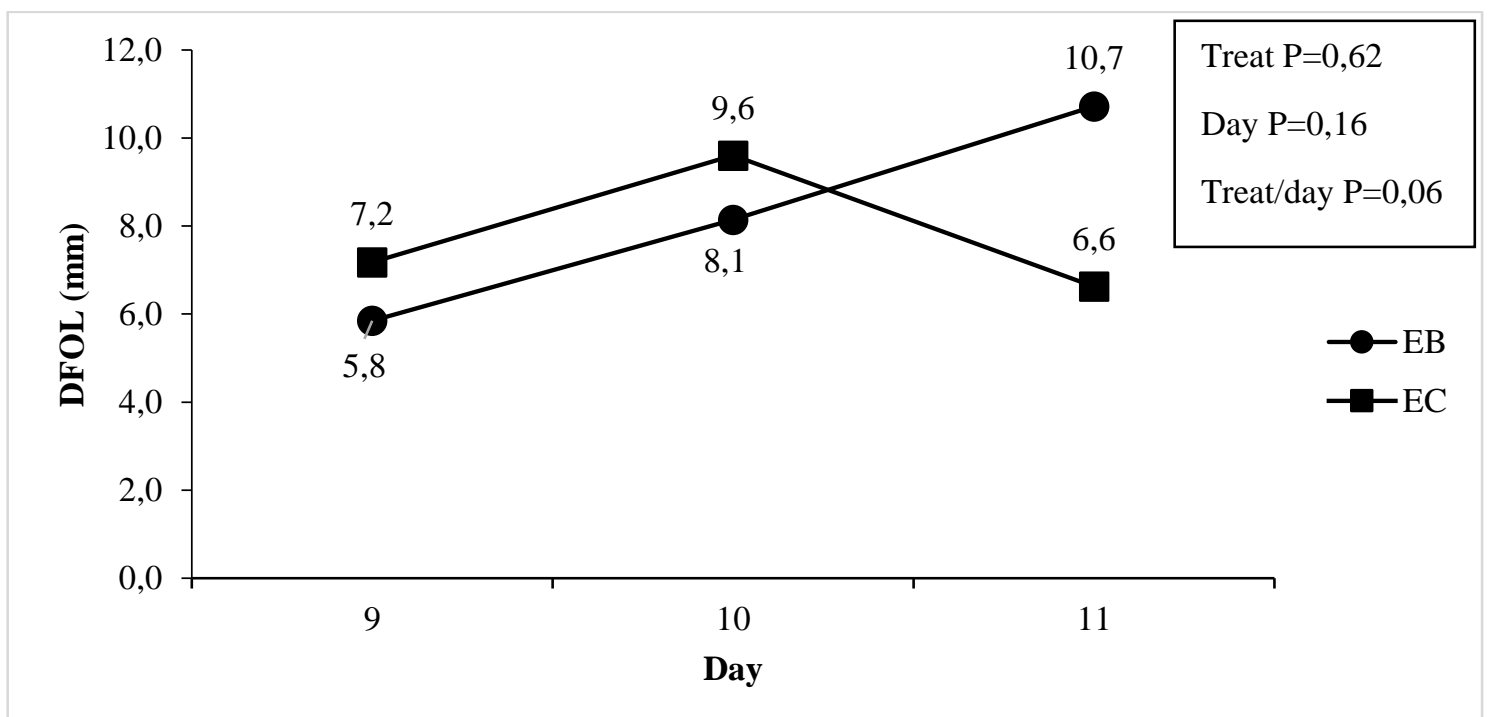

Figure 2. Follicular diameter (DFOL) in mm measured by ultrasonography at D9 to D12 in the subgroups of buffaloes submitted to ovulation induction with estradiol cypionate (EC) or estradiol benzoate (EB).

Although there were differences between the time of ovulation, occurring between D10 and D11 in ECG and more frequently between D11 and D12 in $\mathrm{EBG}$, the pregnancy rate did not have a significant difference between the two groups. Of 69 buffaloes submitted for artificial insemination, 42 resulted in pregnancy, with an overall pregnancy rate of $60.86 \%$. When considering the two different protocols for synchronization of ovulation separately, the pregnancy rate was
$58.8 \%$ and $62.9 \%(\mathrm{P}=0.79)$, for $\mathrm{ECG}$ and $\mathrm{EBG}$, respectively (Table 2 ).

On D11, clinical signs of heat (presence of vaginal discharge, increased uterine tone and ease of passage of the semen applicator in the cervix) were evaluated during artificial insemination, with no significant difference between the experimental groups (Table 3 ). 
Table 2. Pregnancy rate (\%) by ultrasonography examination after timed artificial insemination (TAI) of the buffaloes submitted to ovulation induction treatments with groups of estradiol benzoate (EBG) or estradiol cypionate (ECG)

\begin{tabular}{lccc} 
& \multicolumn{2}{c}{ Treatment } & \multirow{2}{*}{ Total } \\
\cline { 2 - 4 } & ECG & EBG & 69 \\
$\mathrm{~N}^{\circ}$ & 34 & 35 & 42 \\
$\mathrm{~N}^{\circ}$ of Pregnant Females & 20 & 22 & 60.86 \\
Pregnancy Rate $(\%)$ & 58.82 & 62.85 & \\
\hline
\end{tabular}

Table 3. Clinical signs of heat (\%) at the time of artificial insemination of buffaloes submitted to ovulation induction treatments with estradiol cypionate (EC) or estradiol benzoate (EB)

\begin{tabular}{lccc}
\hline \multicolumn{1}{c}{ Clinical Signs of heat } & \multicolumn{2}{c}{ Treatments } & \multirow{2}{*}{ Total } \\
\cline { 2 - 3 }$(\%)$ & EC & EB & 41.9 \\
Presence of vaginal discharge & 32.4 & 51.4 & 91.3 \\
Passing through the cervix & 91.2 & 91.4 & 92.7 \\
Increased uterine tone & 94.1 & 91.4 & \\
\hline
\end{tabular}

\section{DISCUSSION}

Carvalho et al. (2018) evaluated the effect of the administration of EB and EC on the induction, and synchronization, of the ovulation of lactating buffaloes submitted to the TAI protocol during unfavorable reproductive seasons, finding no difference between the experimental groups (EBG vs. ECG) of the variable diameter of the ovulatory follicle and the ovulation rate. In the present study, a similar pattern was found, even though it was carried out under completely different handling and environmental conditions.

Andrade et al. (2012) and Sales et al. (2012) found no significant difference concerning the diameter of the ovulatory follicle, and the ovulation rate between treatments that used EB and EC as ovulation inducers in cattle. As observed in the studies cited, both buffaloes and cattle presented results similar to the present study, the substitution of EB for EC, as an ovulation inducer does not compromise the reproductive indices of the $\mathrm{P} 4$ protocol. The diameter of the ovulatory follicle observed in the buffaloes studied $(9.6 \pm 0.89 \mathrm{~mm}$ vs. $10.7 \pm$ $1.12 \mathrm{~mm} ; \mathrm{P}=0.06$ ), in the ECG and EBG groups respectively, differed from those found by Carvalho et al. (2018) (13.4 $\pm 0.5 \mathrm{~mm}$ vs. $13.0 \pm$ $0.5 \mathrm{~mm} ; \mathrm{P}=0.72$ ).

As observed in studies by Presicse et al. (2004), who found the diameter of the largest follicle with an average of $11.0 \mathrm{~mm}$ for primiparous cows and $13.8 \mathrm{~mm}$ for multiparous cows, and Gimenes et al. (2011), who highlighted the acquisition of ovulatory capacity in buffalo heifers occurring when the diameter of the follicle reaches $8.5 \mathrm{~mm}$ in diameter, it is possible to conclude that the diameter of the ovulatory follicle found in the present study may be related to the age of the buffaloes used, which were mostly primiparous cows.

These results can also be related to the results of the study carried out by Campanile et al. (2010), who observed that, postpartum buffaloes that went through a negative energy balance, had follicular waves with small dominant follicles. Unlike the work carried out in other regions, where animals are often kept in an intensive production system, with balanced diets and fodder with a CP content above $9 \%$ are offered throughout the year. In the present study animals were offered only extensive native lowland pastures, with predominance of the capes marreca (Leersia hexandra Sw.) and colony (Brachiaria mutica), both with CP contents below 7\%, results that are considered by Mison (1990) to be a limiting factor for animal production, considering that they imply less voluntary consumption, reduced digestibility and negative nitrogen balance. However, buffaloes have an efficient feed conversion when compared to cattle, allowing them to maintain excellent productivity in limiting breeding systems (Carvalho et al., 2011).

From a more intensified livestock production point of view, short availability of forage of low nutritional value, as well as the flood and low water regime, are the main factors that limit 
pastoral systems in lowland areas (Townsend et al., 2012). Nevertheless, in the period of river ebb, when the study took place, forage availability was found in these areas, which despite being nutritionally poor when compared to other cultivated forages, was present in large quantities ensuring that the buffaloes had an ideal BCS $(\geq 3)$ for the realization of the TAI, making this biotechnology feasible in the floodplain areas. Studies show that the ECC directly influences the pregnancy rate, with a BCS $>2.5$ being considered the ideal one to perform TAI achieving pregnancy rates of $50 \%$ (Baruselli, 2001).

Regarding follicular growth, there was a higher rate of follicular growth between the administration of PGF $2 \alpha$ and TAI in both groups; however, we observed different results related to the time of ovulation, where in this study there was a significant difference between the removal of the P4 device and the time of ovulation between EC and EB treatments. A similar pattern in relation to the time of ovulation was found in work carried out with cattle, where a longer interval between the removal of the P4 device and the time of ovulation was observed with the use of EB as an ovulation inducer (Martinez et al., 2002). Carvalho et al. (2018) found no difference in relation to the time of ovulation between treatments with EB and EC as ovulation inducers.

Carvalho et al. (2018) observed that the pregnancy rate of buffaloes showed a lower conception rate $(36.2 \%$ vs. $49.5 \% ; \mathrm{P}=0.04)$ for EBG animals compared to ECG, respectively. This fact did not occur in this experiment, where there was no significant difference between the two treatments. High pregnancy rates were found in both groups, with rates higher than those found by Carvalho et al. (2018), who performed his work in an unfavorable breeding season in the Southeast region. Such differences may be related to the climatic characteristics of the Amazonian region as it does not show variations in photoperiod and the animals are in the period in which the work was developed, in lowland areas and in the rainy season, where they would hardly suffer from environmental stress due to the abundance of water, food and shade.

Regarding the reuse of intravaginal progesterone implants used in the present study, Monteiro et al. (2016), evaluating the reuse of implants in buffalo cows, showed that treatment with a new or used progesterone device during the breeding season provides sufficient control of follicular growth to prevent premature ovulation and ensure satisfactory follicular responses to the P4 protocol, not affecting the pregnancy rate.

Chaves Neto et al. (2016) evaluated the correlation of TAI with uterine contractility and the presence of mucus on the day of insemination in relation to the pregnancy rate of crossbred buffaloes raised in an extensive system in a lowland area in the State of Amapá, under conditions similar to the present study. According to these authors, these females were submitted to a protocol based on $\mathrm{P} 4$, with $43.75 \%$ of the animals showing mucus, $97.9 \%$ of the buffaloes had a contracted uterus and the pregnancy rate was $47.9 \%$. The evaluation of the clinical signs of heat in buffaloes, mainly of uterine contractility, is considered by Queiroz (2003), as a significant sign of a positive reaction to the effect of hormonal therapy. Evaluating these signs, it was possible to observe that the treatments with EC and EB showed a positive reaction to hormonal treatment, with uterine contractility being observed more frequently in both treatments.

Although the cost of the TAI protocol that uses $\mathrm{EC}$ as an ovulation inducer is higher, around $\mathrm{R} \$$ 0.65 per animal when compared to the protocol that uses EB, it reduced the number of management from 4 to 3 , lowering the cost of implementation of the TAI, as observed by Carvalho et al. (2018) in research carried out with buffalo and by Andrade et al. (2012) and Sales et al. (2012) in research conducted with cattle. Studies on the application of the TAI technique with EC for vaginal P4 implantation in the Amazonian region are promising, but it needs to be studied regarding the nutritional issue of the females, especially during the flood season in the region. The results obtained indicate viability, allowing small and medium producers to access this type of biotechnology to improve the genetic quality and the production of buffaloes in the Itacoatiara region.

\section{CONCLUSION}

The implantation of TAI using estradiol cypionate to induce ovulation is promising in the region because with only three days of management, it would be easier to move the professional and manage the herd, considering the difficulties 
found in the lowland areas of the region. Also, it would achieve large profits from production and sale of genetically improved animals. The use of estradiol cypionate compared to estradiol benzoate is more advantageous since it reduces the cost of implantation and obtains the same performance in the TAI protocol.

\section{ACKNOWLEDGEMENTS}

Authors thank Coordenação de Aperfeiçoamento de Pessoal de Nível Superior (CAPES) and Programa de Pós-graduação em Ciência Animal e Recursos Pesqueiros (PPGCARP-UFAM) for financial support.

\section{REFERENCES}

ALI, A.; FAHMY, S. Ovarian dynamics and milk progesterone concentrations in cycling and noncycling buffalo-cows (Bubalus bubalis) during Ovsynch program. Theoriogenology, v.68, p.2328, 2007.

ANDRADE, B.H.A.; FERRAZ, P.A.; RODRIGUES, A.S. et al. Eficiência do cipionato de estradiol e do benzoato de estradiol em protocolos de indução da ovulação sobre a dinâmica ovariana e taxa de concepção de fêmeas nelore inseminadas em diferentes momentos. Arch. Vet. Sci., v.17, p.70-82, 2012.

BARUSELLI, P.S.; BARNABE, V.H.; BARNABE, R.C. et al. Effect of body condition score at calving on postpartum reproductive performance in buffalo. Buff. J., v.1, p.53-65, 2001.

BARUSELLI, P.S.; CARVALHO, N.A.T.; GIMENES, L.U. et al. Fixed-time artificial insemination in buffalo. Ital. J. Anim. Sci., v.6, p.107-1118, 2007.

BARUSELLI, P.S.; MADUREIRA, E.H.; BARNABE, V.H. et al. Evaluation of synchronization of ovulation for fixed timed insemination in buffalo (Bubalus bubalis). Braz. J. Vet. Res. Anim. Sci., v.40, p.431-442, 2003.

CAMPANILE, G.; BARUSELLI, P.S.; NEGLIA, G. et al. Ovarian function in the buffalo and implications for embryo development and assisted reproduction. Anim. Reprod. Sci., v.121, p.1-11, 2010.
CARVALHO, N.A.T.; BERNARDES, O.; BARUSELLI, P.S. Desestacionalização dos partos para a produção de leite de búfalas a pasto no centro sul do Brasil. Pesqui. Tecnol., v.8, p.15, 2011.

CARVALHO, N.A.T.; CARVALHO, J.G.S.; SALES, J.N.L. et al. Ésteres de estradiol na indução e sincronização da ovulação de búfalas leiteiras submetidas ao protocolo de IATF durante a estação reprodutiva desfavorável. In: XXXII REUNIÃO ANUAL DA SOCIEDADE BRASILEIRA DE TECNOLOGIA DE EMBRIÕES, 32., 2018, Florianópolis. Anais... Florianópolis: [s.n.], 2018. pag.16-17.

CARVALHO, N.A.T.; SOARES, J.G.; BARUSELLI, P.S. Evolution and perspectives of timed artificial insemination (TAI) programs in Brazil. Indian J. Anim. Reprod., v.39, p.1-8, 2017.

CASSIANO, L.A.P.; MARIANTE, A.S.; MCMANUS, C. et al. Parâmetros genéticos das características produtivas e reprodutivas de búfalos na Amazônia. Pesqui. Agropecu. Bras., v.39, p.451-457, 2004.

CHAVES NETO, A.C.; SILVA, G.A.L.; LIMA, W.F. et al. Perfil da Inseminação artificial em tempo fixo, presença de muco e o status uterino correlacionado com a taxa de prenhez em vacas bubalinas no estado do Amapá. In: CONGRESSO NORTE-NORDESTE DE REPRODUÇÃO ANIMAL, 8., 2016, Terezina. Anais... Belo Horizonte: CBRA, 2016.

GIMENES, L.U.; CARVALHO, N.A.T.; SÁ FILHO, M.F. et al. Ultrassonografic and endocrine aspects of follicle deviation, and acquisition of ovulatory capacity in buffalo (Bubalus bubalis) heifers. Anim. Reprod. Sci., v.123, p.175-179, 2011.

LOURENÇO JUNIOR, J.B. Produção de búfalos na Amazônia. In: SIMPÓSIO DO NÚCLEO DE ESTUDOS EM BOVINOCULTURA, 2., 2005, Seropédica. Anais... Rio de Janeiro: Instituto de Zootecnia da UFRURALRJ, 2005. v.1, p.207226.

MARTÍNEZ, M.F.; COLAZO, M.G.; KASTELIC, J.P.; MAOLETOFT, R.J. Effects of estradiol-17 $\beta$ or estradiol benzoate on follicular dynamics in CIDR-B-treated beef heifers. Theriogenology, v.57, p.382, 2002.

MINSON, D.J. Forage in ruminant nutrition. London: Academic Press, 1990. 483p. 
MONTEIRO, B.M.; SOUZA, D.C.; CORREA, T.B. et al. Ovarian responses of dairy buffalo cows to timed artificial insemination protocol, using new or used progesterone devices, during the breeding season (autumn-winter). Anim. Sci. J., v.87, p.13-20, 2016.

PRESICCE, G.A.; BELLA, A.; TERZANO, G.M. et al. Postpartum ovarian follicular dynamics in primiparous and pluriparous Mediterranean Italian buffaloes (Bubalus bubalis). Theriogenology, v.63, p.1430-1439, 2004.

QUEIROZ, A.C.L. Sincronização do ciclo estral e inseminação artificial em tempo fixo em búfalas criadas em várzea no município de SantarémPará. 2003. 125f. Dissertação (Especialização em Produção e Sanidade Animal) - Centro de Produção e Sanidade Animal, Universidade Federal Rural da Amazônia, AM.
SALES, J.N.S.; CARVALHO, J.B.P.; CREPADI, G.A. et al. Effects of two estradiol esters (benzoate and cypionate) on the induction of synchronized ovulations in bosindicus cows submitted to a time artificial insemination protocol. Theriogenology, v.78, p.510-516, 2012.

SINGH, J.; BALHARA, A.K. New approaches in buffalo artificial insemination programs with special reference to India. Theriogenology, v.86, p.194-199, 2016.

TOWNSEND, C.R.; COSTA, N.L.; PEREIRA, R.J.A. Pastagens nativas da Amazônia. Porto Velho: Embrapa, 2012. 25p. (Documentos, n.149).

VAN SOEST, P.J.; ROBERTSON, J.B.; LEWIS, B.A. Methods for dietary fiber, neutral detergent fiber, and nonstarch polysaccharides in relation to animal nutrition. J. Diary. Sci., v. 74, p. 35833597, 1991. 